\title{
Effects of laboratory maintenance on the nature of surface reactive antigens of Neisseria gonorrhoeae
}

\author{
R. J. ARKO, J. C. BULLARD, AND W. P. DUNCAN \\ From the Venereal Disease Research Branch, Center for Disease Control, Public Health Service, \\ U.S. Department of Health, Education, and Welfare, Atlanta, Georgia, USA
}

\section{Summary}

The extensive in vitro cultivation methods used in propagating and maintaining gonococcal cells were found to affect their virulence, antigenicity, and ultrastructure. Adapting a laboratory-maintained strain of gonococci to animal virulence resulted in two lines of pilated cells with similar colonial morphologies. The animal-adapted cells, however, had a greater amount of extracellular pili and a more prominent peptidoglycan cell wall layer. They were also more resistant to the bactericidal effects of guinea-pig complement and more reactive in macroagglutination and bactericidal tests with strain-specific gonococcal antibody. In comparative guinea-pig protection trials, formalin-fixed cells of the animal-adapted cell line were 500 times more effective as immunogens than the laboratorymaintained cell line.

\section{Introduction}

The effectiveness of certain antigenic components of Neisseria gonorrhoeae in immunological procedures can be influenced by the media and methods used in gonococcal cell production and maintenance. A number of enriched laboratory media will readily support the growth of gonococci; however, the characterization of colony types ( $T$ ) by Kellogg, Peacock, Deacon, Brown, and Pirkle (1963) and the later correlation of $\mathrm{T} 1$ and $\mathrm{T} 2$ with increased virulence for human volunteers (Kellogg, Cohen, Norins, Schroeter and Reising, 1968) has resulted in wide acceptance of a semisolid, translucent, enriched agar medium for making selective transfers of gonococcal colony types. Thayer and Martin (1966) added the antibiotics vancomycin, colistin, and nystatin (VCN) to a chocolate agar to produce a medium more selective for the isolation of pathogenic Neisseria species.

Received for publication March 12, 1976

Address for reprints: Dr R. J. Arko, Senior Veterinary Officr USPHS, Bldg 1, Room 3246, V.D. Research Branch, Center for Disease Control, Atlanta, Georgia 30333 USA
The effects of antibiotics and of extensive laboratory transfer on the antigenic composition and virulence of gonococcal isolates have been questioned for many years. Lack of a suitable infection model has, however, restricted the study of this problem.

In this research the recently developed mouse and guinea-pig models of gonococcal infection (Arko, 1972) were used to study the virulence, antigenic reactivity, and ultrastructure of a gonococcal isolate which has been maintained by selective serial transfers on laboratory media for over 5 years.

\section{Material and methods}

In our laboratory the $\mathrm{N} 9$ isolate of gonococci has been used in numerous immunological studies involving humans, chimpanzees, and laboratory animals. The growth and maintenance of this isolate require the selective transfer of colonies on to a $\mathrm{Gc}$ Base ( $\mathrm{GcB}$ ) medium, enriched with a defined supplement, Isovitalex (Baltimore Biological Laboratories, Baltimore, Md. USA) with or without selective VCN antibiotics. The harvested colonies are preserved by either lyophilization or freezing at $-70^{\circ} \mathrm{C}$. This isolate has been transferred at least 300 times since its isolation from an infected patient.

Using the $\mathrm{T} 1$ and $\mathrm{T} 2$ colonies of the laboratorymaintained N9 isolate, we obtained subcutaneous chamber infections in mice which were immuno-suppressed with $0.5 \mathrm{mg}$. dexamethazone (Schering Co., Bloomfield, N.J., USA) 1 day before and daily for 3 days after gonococcal inoculation (Arko, 1973). The N9 isolate was prepared for animal inoculation by streaking the desired colony types on to agar $\mathrm{GcB}$ medium and incubating the plates for $20 \mathrm{hrs}$ at $36^{\circ} \mathrm{C}$ in a candle-extinction jar. The surface growth on these plates was harvested with a sterile cotton swab and suspended in trypticase soy broth (TSB $30 \mathrm{~g} /$ litre of distilled water), and the suspension was adjusted to an optical density (OD) of 0.5 in a $13 \times 100 \mathrm{~mm}$ glass tube with a Leitz Spectrophotometer set at $535 \mathrm{~nm}$. The suspension of cells was then injected into mouse subcutaneous chambers in $0.2-\mathrm{ml}$ amounts. The inoculum dose was quantitated by making 10-fold serial dilutions of the stock suspension and inoculating three plates of $\mathrm{GcB}$ medium with $0.1-\mathrm{ml}$ amounts from each of the $1 \times 10^{-5}$, $1 \times 10^{-6}$, and $1 \times 10^{-9}$ dilutions. The colony forming units (CFU) of gonococci were counted on each plate after incubation for $24 \mathrm{hrs}$ at $36^{\circ} \mathrm{C}$ in a candle-extinction jar. Fluid specimens of $0.05 \mathrm{ml}$ were obtained from each 
mouse chamber at $1,3,6,8$, and $24 \mathrm{hrs}$ after injection and streaked on to plates of $\mathrm{GcB}$ medium. Growth from these plates was re-suspended in TSB and injected into subcutaneous chambers in additional mice. After chamber adaptation of the T1 cells of N9, a chamber-infective dose 50 per cent. $\left(\mathrm{CID}_{50}\right)$ was determined by injecting known numbers of gonococci into the chambers of nonimmunosuppressed (normal) mice. Fluid was withdrawn from each mouse at 3-day intervals and streaked on to GcB plates which were incubated as previously described. The $\mathrm{CID}_{50}$ was determined by graphic interpolation between the CFUs of gonococci producing more than and less than 50 per cent. infection rates.

The survival in vivo and in vitro of the laboratorymaintained and mouse-adapted $\mathrm{T} 1$ cells of $\mathrm{N} 9$ were compared in normal mouse chambers and in phosphate buffered saline (PBS), pH 7·2. Cells of T1 colonies from both the laboratory-maintained and mouse-adapted N9 lines were suspended in PBS to optical density 0.5 levels, and $0 \cdot 2-\mathrm{ml}$ amounts of each were immediately injected into two groups of four mice each. The remaining suspensions of cells were maintained in PBS at $35^{\circ} \mathrm{C}$ for up to $24 \mathrm{hrs}$. Specimens were obtained from each mouse chamber and from the PBS suspension at 1-, 3-, 6-, 8-, and 24-hr intervals after injection and streaked on $\mathrm{GcB}$ plates.

A guinea-pig immunization study was conducted with three formalin-fixed immunogens prepared from the $T 1$ colonies of the laboratory-maintained and mouse-adapted N9 cell lines. Thirty $100 \times 15 \mathrm{~mm}$ agar plates of $\mathrm{GcB}$ medium + Isovitalex were heavily streaked with the mouse-adapted $\mathrm{N} 9 \mathrm{~T} 1$ cells. After incubation at $36^{\circ} \mathrm{C}$ for $20 \mathrm{hrs}$ in a candle-extinction jar, these plates were removed and examined microscopically to determine the colony types present. All plates contained more than 95 per cent. T1 colonies and were immediately harvested with individual glass ' $L$ ' rods into three weighed centrifuge tubes, each containing $50 \mathrm{ml}$ sterile 0.85 per cent. saline. The three tubes were centrifuged at $1,500 \mathrm{G}$ for $30 \mathrm{~min}$. The supernate was removed and the tubes were reweighed. The wet weight of cells in each tube was determined in grams and adjusted to 5 per cent. (wet cell weight/ volume) with the supernate which was previously removed from each tube. A $2-\mathrm{ml}$ aliquot of the 5 per cent. cell suspension was removed from each tube and diluted 1:5 with sterile saline containing 5 per cent. neutral formalin. This portion of cells was kept at $4^{\circ} \mathrm{C}$ and used in a macroscopic agglutination test for gonococcal antibodies (Arko, 1974). The remaining cell suspension was fixed with $0 \cdot 1$ per cent. neutral formalin and held at $4^{\circ} \mathrm{C}$ until injected into guinea-pigs.

A series of 41, 250-g., male, Hartley strain guinea-pigs was randomly divided into four groups, three of which received immunizations with the above individual immunogen preparations. Each animal was given four $1-\mathrm{ml}$ intramuscular injections of the respective immunogen at 1 week intervals. The fourth group served as nonimmunized challenge controls. Three days after the fourth injection, two stainless steel chamber implants were placed in each guinea-pig of each group (Arko, 1973). Seven days later the resistance of each guinea-pig was tested by inoculating a known number of guinea-pig-virulent N9 $\mathrm{T} 1$ cells into the subcutaneous chambers. The guinea-pig chambers were cultured at 3-day intervals after challenge and culture-negative chambers were rechallenged the following day with a 10 to 100 -fold increase in inoculum CFUs.

The antigen sensitivity and specificity of the laboratorymaintained and mouse-adapted N9 T1 cells for gonococcal antibodies to the $\mathrm{N} 9$ isolate were compared by a previously described microbactericidal test of Tramont, Sadoff, and Artenstein (1974) and by a macroagglutination procedure. The A, G, C, and N9 immune sera in the tests were obtained from guinea-pigs previously infected in subcutaneous chambers for 15 days or longer with the respective gonococcal isolate.

The $\mathrm{T} 1$ cell ultrastructure of the laboratory-maintained and mouse-adapted N9 cell lines was studied by electron microscopy to determine if any morphological differences could be found to correlate with the virulence variation observed in the mouse chambers. T1 cells of the laboratorymaintained and mouse-adapted cultures, grown on plates of $\mathrm{GcB}$ medium for $18 \mathrm{hrs}$ at $36^{\circ} \mathrm{C}$ or in a liquid medium supplemented with 2 per cent. yeast extract (Frantz, 1942), and cells in fluid from infected mouse chambers were examined by whole-mount and ultrathin-section preparation. Whole mounts were prepared by picking $\mathrm{T} 1$ colonies from $\mathrm{GcB}$ plates with a sterile platinum loop and suspending the cells in sterile distilled water. A drop of the suspension was placed on Formvar-coated copper grids, blotted dry, negatively stained with 2 per cent. aqueous uranyl acetate, $\mathrm{pH} 4.0$, for 15 sec., again blotted dry, and examined with a Philips model 200 transmission electron microscope operating at an accelerating voltage of $60 \mathrm{kV}$.

For thin sections the organisms were collected with sterile cotton swabs or by centrifugation $(1,500 \mathrm{G}$ for $10 \mathrm{~min}$.) and suspended in 2 per cent. glutaraldehyde in $0.1 \mathrm{Mol}$ sodium cacodylate buffer, $\mathrm{pH} 7.4$, for $2 \mathrm{hrs}$ at room temperature. A pellet was formed by centrifuging in a Servall Super Speed centrifuge at $16,000 \mathrm{G}$ for $15 \mathrm{~min}$. The pellets were suspended in a $0.1 \mathrm{Mol}$ sucrose cacodylate buffer rinse at $4^{\circ} \mathrm{C}$ overnight. They were postfixed in 1 per cent. buffered osmium tetroxide for $1 \mathrm{hr}$ at room temperature, centrifuged as before, dehydrated in graded ethanols, infiltrated with propylene oxide, and embedded in Maraglas.

Ultrathin sections were cut on a Servall Porter-Blum MT-1 ultra-microtome, picked up on bare copper grids, stained with uranyl acetate and lead citrate (Reynolds, 1963), and examined in the electron microscope.

\section{Results}

The laboratory-maintained $\mathrm{T} 1$ cells of $\mathrm{N} 9$ did not survive more than $6 \mathrm{hrs}$ when $1 \times 10^{7} \mathrm{CFU}$ or less was injected into the subcutaneous chambers of normal mice. However, mouse-chamber infection was obtained in dexamethasone-treated mice by injection and subpassage of cells on $\mathrm{GcB}$ plates at $6-\mathrm{hr}$ intervals. Once an infection had persisted 5 days or longer the N9 T1 cells became highly virulent for normal mouse subcutaneous chambers. A mouse $\mathrm{CID}_{50}$ of approximately $1 \times 10^{2} \mathrm{CFU}$ was determined for the T1 cells after mouse adaptation.

When we compared the laboratory-maintained and mouse-adapted cultures of N9 T1, we found that the 
in vitro survival time for both was approximately $8 \mathrm{hrs}$ for $1 \times 10^{7}$ cells per $\mathrm{ml}$ in $35^{\circ} \mathrm{C}$ PBS. In contrast, the mouse-chamber survival time for the laboratory-maintained N9 was $6 \mathrm{hrs}$ or less, but the mouse-adapted $\mathrm{N} 9$ cells remained viable for up to 30 days.

In preparing formalinized immunogens from the

TABLE I Relative resistance of normal and N9 immunized guinea-pigs to chamber infection with virulent N9 type 1 cells of $\mathrm{N}$. gonorrhoeae

\begin{tabular}{|c|c|c|c|c|c|c|c|}
\hline \multirow{2}{*}{$\begin{array}{l}\text { Formalin- fixed } \\
\text { immunogen }^{\mathrm{a}}\end{array}$} & \multirow{2}{*}{$\begin{array}{l}\text { Immunogen } \\
\text { culture medium }\end{array}$} & \multicolumn{5}{|c|}{ Challenge in $C F U^{\mathrm{b}}(\text { Number infected/number challenged })^{\mathrm{c}}$} & \multirow{2}{*}{$\begin{array}{l}\text { Interpolated } \\
\text { guinea-pig ID } \\
\text { (in } C F U)\end{array}$} \\
\hline & & $2.0 \times 10^{2}$ & $1.0 \times 10^{4}$ & $2.5 \times 10^{5}$ & $4.0 \times 10^{6}$ & $5 \cdot 0 \times 10^{7}$ & \\
\hline $\begin{array}{l}\text { Mouse virulent N9 T1 } \\
\text { cells } \\
\text { Mouse virulent N9 T1 }\end{array}$ & Gc base + Isovitalex & $0 / 11$ & $2 / 11$ & $2 / 9$ & $4 / 7$ & $0 / 3$ & 500,000 \\
\hline $\begin{array}{l}\text { cells } \\
\text { Laboratory mouse }\end{array}$ & Gc base + VCN ${ }^{d}+$ Isovitalex & $0 / 12$ & $7 / 12$ & $5 / 5$ & NT & NT & 10,000 \\
\hline $\begin{array}{l}\text { avirulent N9 T1 cells } \\
\text { Normal controls }\end{array}$ & $\begin{array}{l}\text { Gc base + Isovitalex } \\
\text { None }\end{array}$ & $\begin{array}{c}0 / 8 \\
10 / 10\end{array}$ & $\begin{array}{l}7 / 8 \\
\text { NT }\end{array}$ & $\begin{array}{l}1 / 1 \\
\text { NT }\end{array}$ & $\begin{array}{l}\text { NT } \\
\text { NT }\end{array}$ & $\begin{array}{l}\text { NT } \\
\text { NT }\end{array}$ & $\begin{array}{r}1,100 \\
20\end{array}$ \\
\hline
\end{tabular}

Immunization consisted of giving four 1-ml intramuscular injections of each immunogen at 1 week intervals

Each immunogen was prepared to contain 5 per cent. (wet cell wt/volume) of pilated type 1 cells fixed with $0 \cdot 1$ per cent. formalin.

bChallenge was initiated 10 days after the last immunization by injecting a $0.2 \mathrm{ml}$ suspension containing the indicated number of colony forming units (CFU) of gonococci into the right subcutaneous chamber of each animal.

chamber fluid specimens were removed at 3-day intervals and cultured on Gc base medium; culture negative animals were rechallenged with

the next larger number of gonococci on the following day.

dVCN antibiotic inhibitors and Isovitalex were obtained from BBL, Cockeysville, Maryland, USA

TABLE II Reactivity of mouse avirulent laboratory-maintained and mouse-adapted type 1 cells of N9 gonococci in agglutination and bactericidal serological procedures

\begin{tabular}{|c|c|c|c|c|c|c|}
\hline \multirow{2}{*}{ Titre } & \multirow{2}{*}{ Antigens used } & \multirow{2}{*}{ Normal serum } & \multicolumn{4}{|c|}{ Guinea-pig Gc antisera ${ }^{\mathrm{b}}$} \\
\hline & & & $A$ & $G$ & $C$ & N9 \\
\hline Macroagglutination $^{\mathrm{a}}$ & $\begin{array}{l}\text { Laboratory-maintained N9 cells } \\
\text { Mouse-virulent N9 cells }\end{array}$ & - & $\overline{1: 4}$ & - & $\overline{-}$ & $\begin{array}{l}1: 4 \\
1: 64\end{array}$ \\
\hline Serum bactericidal $^{c}$ & $\begin{array}{l}\text { Laboratory-maintained N9 cells } \\
\text { Mouse-virulent N9 cells }\end{array}$ & $1: 8$ & $\begin{array}{l}1: 16 \\
1: 8\end{array}$ & $\begin{array}{l}1: 8 \\
1: 8\end{array}$ & $\begin{array}{l}1: 16 \\
1: 16\end{array}$ & $\begin{array}{l}1: 8 \\
1: 256\end{array}$ \\
\hline
\end{tabular}

a Macroagglutination of formalin-fixed type 1 cells read after $60 \mathrm{~min}$. incubation with antisera

bGonococcal antisera was obtained from guinea-pigs having recovered from chamber infections with the respective serotype of gonococci

cSerum microbactericidal titre was determined as the dilution of serum which produced a 50 per cent. reduction in cell survival after incubation for $90 \mathrm{~min}$. with test antigen



FIG. 1 Negative stain of whole mount preparation of the mouse-adapted N9 cells, showing 'bulletshaped' pilated diplococci. $\times 18,750$
N9 $\mathrm{T} 1$ cells, differences in cell mass yield were noted between the laboratory-maintained and mouseadapted cells grown on $\mathrm{GcB}$ medium and between the mouse-adapted cells grown on $\mathrm{GcB}$ and $\mathrm{GcB}+\mathrm{VCN}$ media. The laboratory-maintained $\mathrm{N} 9$ cells grown on thirty plates of $\mathrm{GcB}$ medium yielded only $2.7 \mathrm{~g}$ $\mathrm{T} 1$ cells, in comparison to the mouse-adapted cells cells, showing pilated diplococci. $\times 18,750$ 


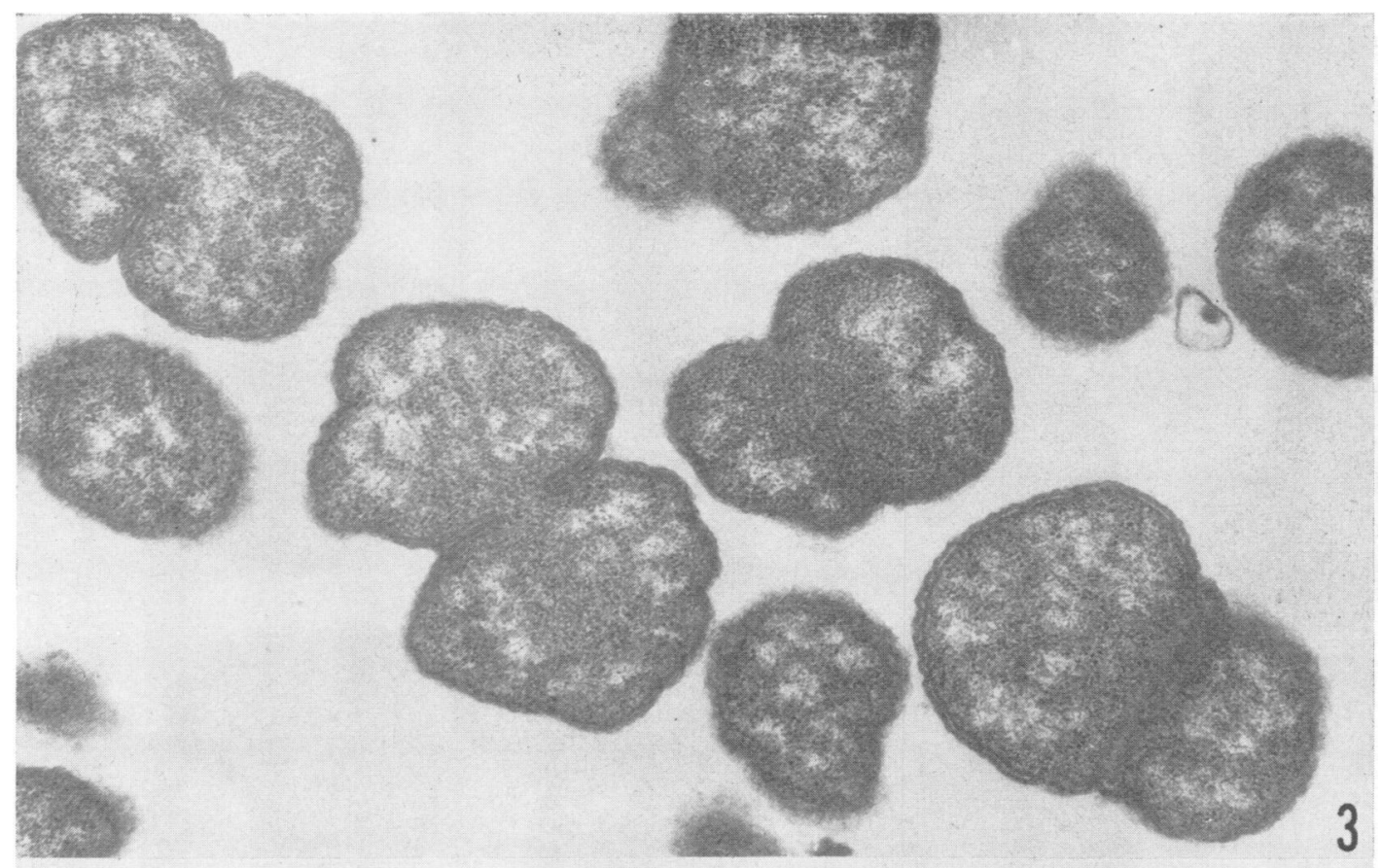

3



FIG. 3 Ultrathin section of laboratory-maintained N9 T1 cells $\times 41,125$
FIG. 4 Higher magnification of ultrathin section of laboratory-maintained N9 T1 cells.

$O M=$ outer cell membrane, $P S=$ periplasmic space, $C M=$ cytoplasmic membrane. $\times 88,125$ 

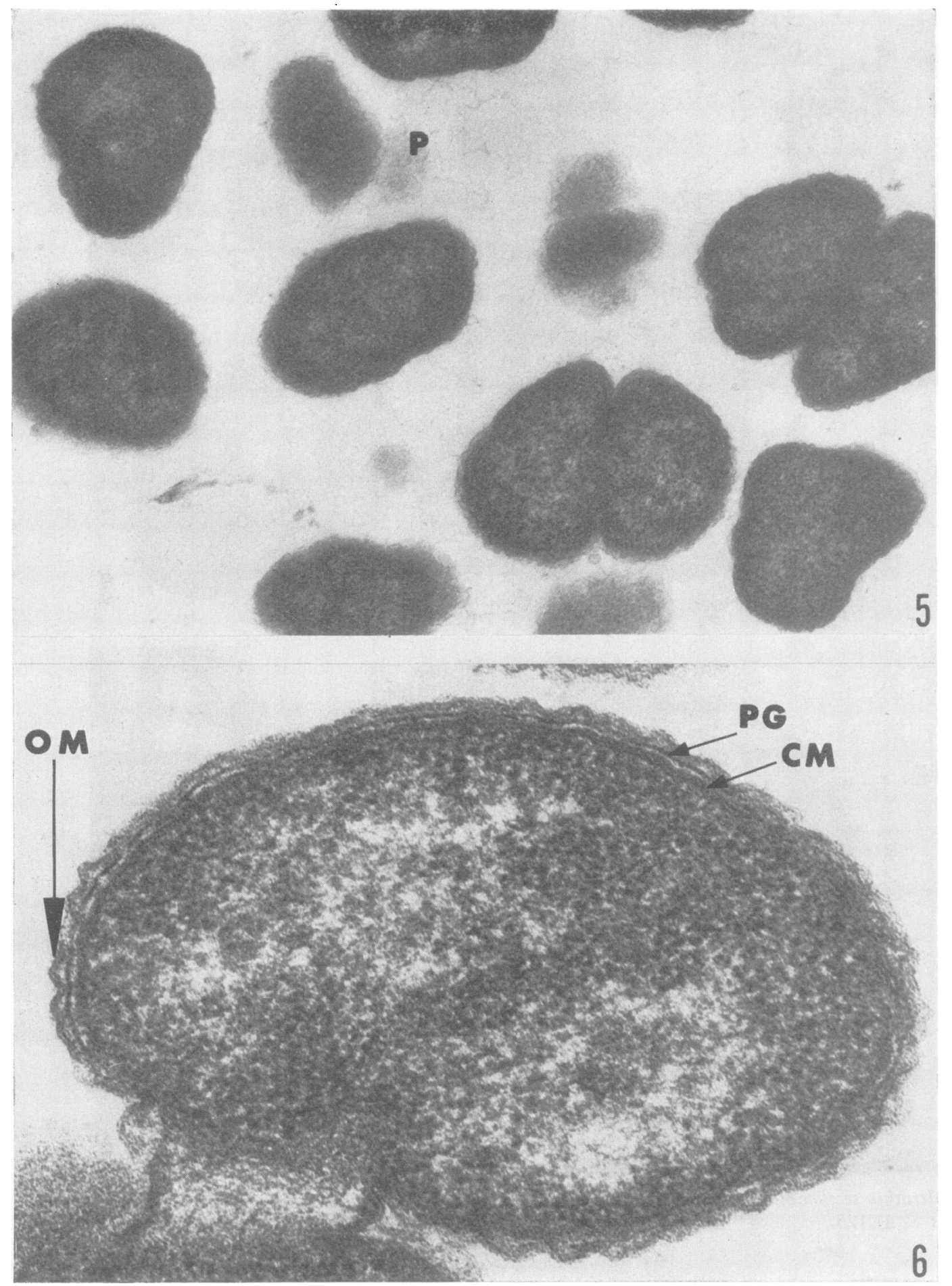

FIG. 5 Thin section of N9 T1 mouse-adapted cells. $P=$ aggregates of pili. $\times 41,125$
FIG. 6 Thin section of mouse-adapted N9 T1 cells. $O M=$ outer cell membrane, $P G=$ peptidoglycan layer, $C M=$ cytoplasmic membrane. $\times 141,000$ 
which yielded $5 \mathrm{~g}$. However, the mouse-adapted cells produced only $2.6 \mathrm{~g}$ when VCN was incorporated into the growth medium.

Guinea-pigs receiving $50 \mathrm{mg}$ of the three above immunogens developed tissue swelling of approximately 3 by $1 \mathrm{~cm}$ at the injection site within $48 \mathrm{hrs}$. The tissue response persisted in most animals for 4 to 7 days. The postimmunization challenge results for the three immunogen preparations tested in guinea-pigs are shown in Table $I$. The results of serological tests with antigens prepared from N9 T1 cells of the laboratory and mouse-adapted cultures are shown in Table II.

In the electron microscopic study we compared characteristics in the appearance of $\mathrm{T} 1$ cells from both the laboratory-maintained and animal-virulent N9 cultures. When incubated for $18 \mathrm{hrs}$ on a semisolid $\mathrm{GcB}$ medium and negatively stained, $\mathrm{T} 1$ cells from these cultures displayed abundant surface pili (Figs 1 and 2), as previously described by Jephcott, Reyn, and Birch-Anderson (1971) and Swanson, Kraus, and Gotschlich (1971). However, the animalvirulent $\mathrm{T} 1$ cells sectioned directly from the chamber fluid of mice that had been infected for $72 \mathrm{hrs}$ or longer were devoid of attached surface pili. As shown in Fig. 2, T1 cells of the laboratory-maintained N9 culture grown on $\mathrm{GcB}$ and negatively stained appeared as typical diplococci, but $\mathrm{T} 1$ cells from the animal-virulent culture prepared under the same conditions appeared pleomorphic or 'bullet-shaped' (Fig. 1).

In ultrathin sections of the laboratory-maintained N9 cells grown on $\mathrm{GcB}$ medium for $18 \mathrm{hrs}$, the cell wall appeared to consist of a relatively thick, doublelined outer membrane separated by an irregular periplasmic space from a double-lined cytoplasmic membrane (Figs 3 and 4). Relatively few extracellular pili were seen in thin sections of the laboratory-maintained N9 culture. Thin sections prepared under the same conditions from the animal-virulent cultures of N9 showed much larger amounts of extracellular pili as well as greater electron density of the cell wall layers (Figs 5 and 6 ). In addition, the peptidoglycan layer, a dense granular lamina between the outer and cytoplasmic membranes (Fig. 6), showed much greater development than in the laboratory-maintained culture (Fig. 4). Although pili appeared on $\mathrm{T} 1$ cells grown on semisolid medium, they were not present on cells in sections of gonococci grown in Frantz liquid medium (Fig. 7) or in infected animal fluid (Fig. 8).

Thin sections prepared from the animal-virulent



FIG. 7 Thin section of mouse-adapted N9 T1 cells grown in Frantz medium, showing marked cellular pleomorphism and autolysis. $\times 41,125$ 

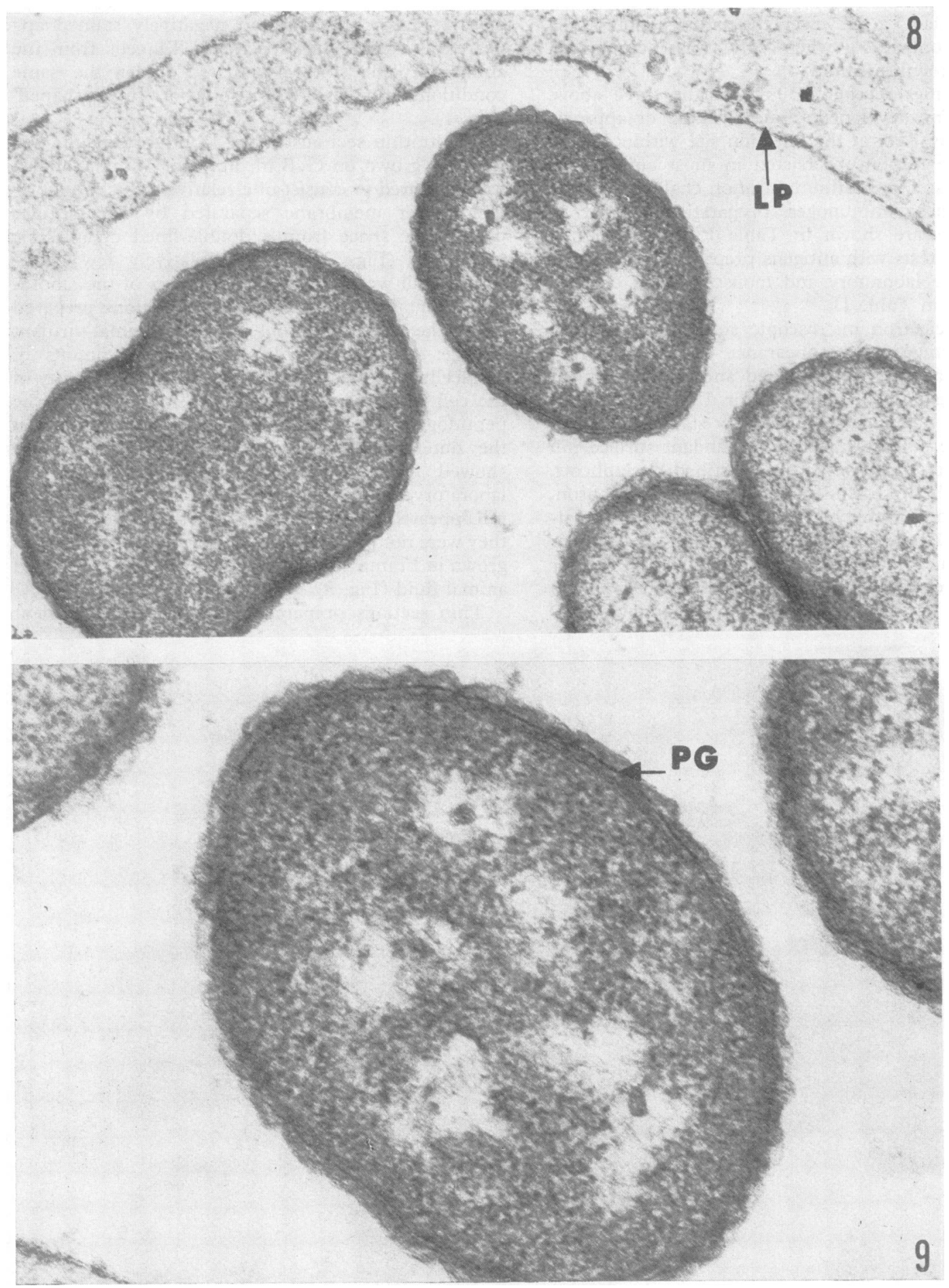

FIG. 9 Higher magnification of Fig. 8, showing

FIG. 8 Thin section of mouse-adapted N9 cells in infected mouse chamber fluid plus a portion of a leucocyte pseudopod LP. $\times 64,050$ prominent peptidoglycan layer $P G . \times 128,100$ 


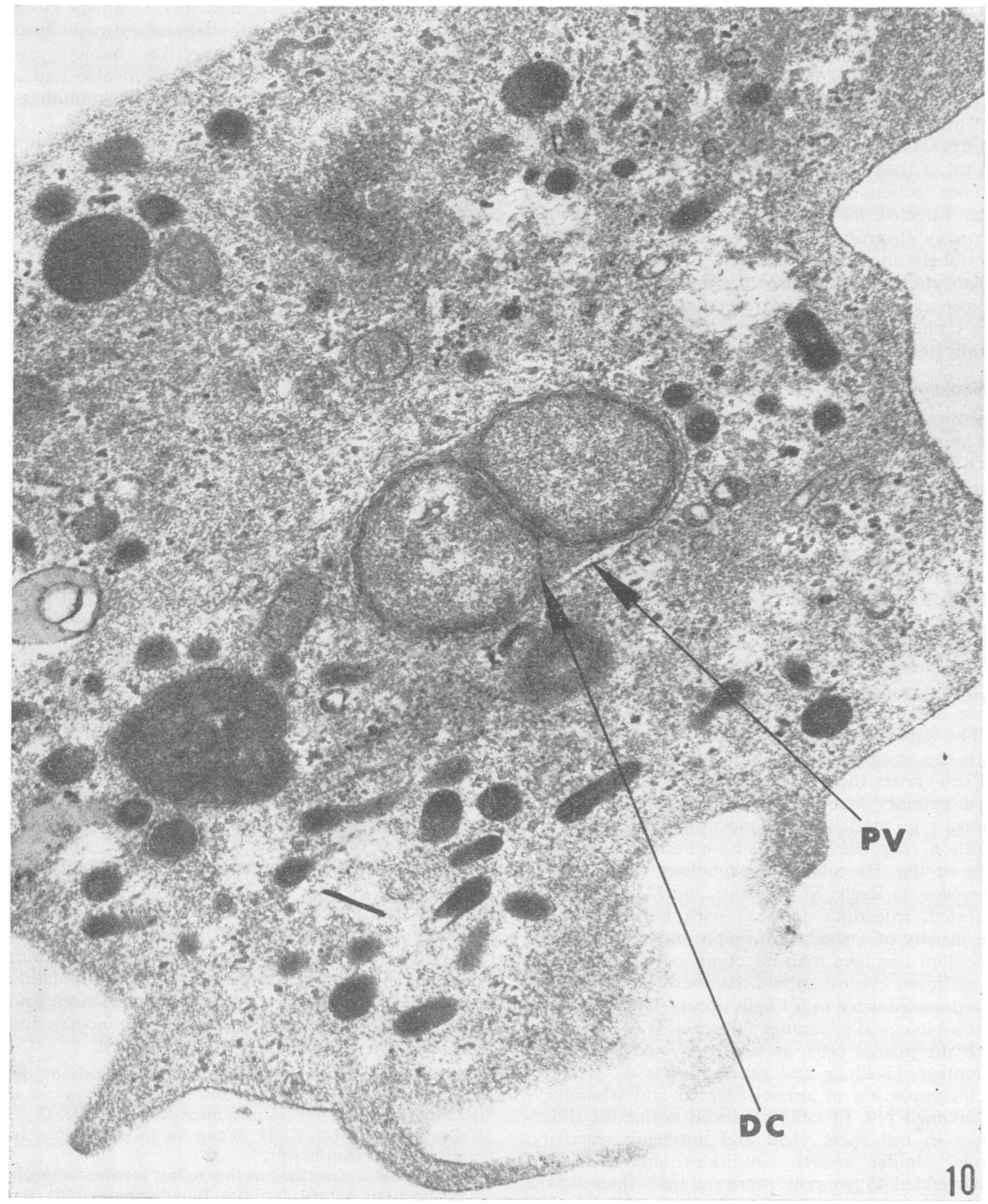

FIG. 10 Thin section of a leucocyte in mouse chamber fluid containing engulfed diplococci DC.

$P V=$ phagocytic vacuole.$\times 37133$ 
N9 cells grown for $18 \mathrm{hrs}$ in the Frantz (1942) liquid medium showed greater variation in cellular morphology and structure (Fig. 7) than did similar cells grown on a semisolid GcB medium (Fig. 5). Many of the atypical cells (Fig. 7) do not appear to have a peptidoglycan layer and seem to be undergoing autolysis. Other cells appear to have cell wall structure typical of the animal-virulent $\mathrm{T} 1$ cells.

Thin sections made of diplococci present in fluid from infected mouse chambers appear to have a relatively electron-dense cell wall with a prominent peptidoglycan layer (Figs 8 and 9). Although mouse phagocytic cells were present (Figs 8 and 10), most diplococci were found extracellularly. However, an intact phagocyte with at least two gonococcal cells within phagocytic vacuoles may be seen in Fig. 10 .

\section{Discussion}

The propagation and maintenance of gonococcal cells for long periods by the selective transfer of colonies on a conventional GcB medium may, as shown in Tables I and II, have a demonstrable effect on their virulence and antigenicity. The laboratory-maintained N9 T1 cells in this study retained their typical colonial morphology; however, their continuous propagation in vitro may have contributed to their relative loss of virulence for chambers in laboratory animals. Adaptation of the laboratory-maintained N9 culture to virulence for animal chambers has resulted in two lines of $\mathrm{T} 1$ cells which are indistinguishable in colony morphology but have differences in virulence, antigenicity, and cell ultrastructure.

The presence of surface pili (Figs 1 and 2) on both the animal-adapted and laboratory-maintained $\mathrm{T} 1$ cells raises the question of the importance of pili as a primary virulence factor in the mouse and guinea-pig models of gonococcal infection. In addition, chamber infections have been obtained with cells of the T3 colonial morphology (Arko, 1974). However, as Veale, Smith, Witt, and Marshall (1975) reported, infections induced with nonpilated cells are usually of a shorter duration and require larger inoculum numbers than infections with pilated cells. In addition, in most animal chambers, a gradual shift to a predominance of $T 1$ cells occurs, which suggests that a biological advantage for survival in vivo exists with the pilated cells, as seen previously in human volunteers (Kellogg and others, 1963).

A comparison of animal-adapted and laboratorymaintained N9 $\mathrm{T} 1$ cells produced noticeable differences in cell mass yield and antigenic reactivity. Under similar growth conditions, animal-adapted cells yielded 45 per cent. more cell mass than did the laboratory-maintained $\mathrm{T} 1$ cells. In addition, they were more effective in stimulating protective immunity. Guinea-pigs immunized with virulent $\mathrm{T} 1$ cells (Table I) resisted challenge with 25,000 times more gonococci than nonimmunized animals, and approximately 500 times more than animals given similar immunization with laboratory-maintained T1 cells. The addition of selective antibiotic inhibitors, VCN, to the culture medium also had a detrimental effect on cell mass yield and immunization effectiveness (Table I).

Gonococcal T1 cells produced by culture for $18 \mathrm{hrs}$ in Frantz liquid medium supplemented with 2 per cent. yeast extract have also been found to be less effective immunogens when compared with similar cells harvested from a semisolid $\mathrm{GcB}$ medium (Arko, unpublished data). As shown in Fig. 7, approxiproximately 50 per cent. of the cells harvested from the Frantz medium have an atypical cell wall structure and appear to be autolysing, which may have contributed to their decreased effectiveness as immunogens.

In thin sections, the degree of development of peptidoglycan layer appeared to be the most differentiating cell characteristic between animal-adapted and laboratory-maintained cells. The prominent peptidoglycan layer of the animal-adapted N9 cells (Figs 6 and 9) is similar to that described by Novotny, Short and Walker (1975) for gonococcal cells found in human pus and for cell walls of Acinetobacter (Thornley, 1975). Although the peptidoglycan layer is believed to be weakly antigenic and to function primarily in cell morphology, it has not as yet been isolated or tested as a gonococcal immunogen. However, Buchanan and Arko (in preparation) found that the closely associated cell outer membranes and antigens isolated from them are capable of stimulating strain-specific, bactericidal antibodies in guinea-pigs, which were subsequently demonstrated to have a significant level of strain-specific immunity to the immunizing isolate of gonococci. In addition, the level of serum bactericidal and indirect fluorescent antibody has recently been demonstrated to have a positive correlation with the relative resistance of immunized male chimpanzees to urethral and pharyngeal gonococcal infection (Arko, Duncan, Brown, Peacock, and Tomizawa, 1976). It appears that, in these animal models, other surface reactive antigens, in addition to pili, may play an important role in gonococcal cell virulence and in stimulating protective antibodies. The further isolation and characterization of these antigens as immunogens and serological test reagents seems warranted.

The authors thank the Viral Pathology Branch of the Virology Division, Center for Disease Control, for use of the Philips Model 200 electron microscope and Dr. D. S. Kellogg, Jr. and Dr. K. H. Wong for their assistance in preparing this manuscript.

The research described in this report involved animals maintained in animal facilities fully accredited by the American Association for the Accreditation of Laboratory Animal Care.

Use of trade names is for identification only and does not constitute endorsement by the Public Health Service or by the U.S. Department of Health, Education, and Welfare. 


\section{References}

ARko, R. J. (1972) Science, 177, 1200 (1973) Lab. Anim. Sci., 23, 105 (1974) F. infect. Dis., 129, 451

-, Duncan, W. P., Brown, W. J., Peacock, W. L., and Tomizawa, T. (1976) Ibid., 133, 441

BuChaNAN, T. M., and ARKo, R. J. (In preparation.) f infect. Dis.

FRANTZ, I. D. (1942) f. Bact., 43, 757

JephCott, A. E., Reyn, A., and Birch-ANDERson, A. (1971) Acta path. microbiol. scand., 79B, 437

KellogG, D. S., JR., Cohen, I. R., Norins, L. C., SCHROEter, A. L., and ReIsing, G. (1968) Ibid., 96, 596
—, Peacock, W. L., Jr., Deacon, W. E., Brown, L., and PIRKLE, C. I. (1963) Ibid., 85, 1274

Novotny, P., Short, J. A., and WALkeR, P. D. (1975) F. med. Microbiol., 8, 413

ReYNolds, E. S. (1963) F. Cell Biol., 17, 208

Swanson, J., Kraus, S. J., and Gotschlich, E. C. (1971) F. exp. Med., 134, 886

Thayer, J. D., and Martin, J. E., JR. (1966) Publ. Hlth Rep. (Wash.), 81, 559

Thornley, M. J. (1975) Crit. Rev. Microbiol., 4, 65

Tramont, E. C., Sadoff, J. C., and Artenstein, M. S. (1974) F. infect. Dis., 130, 240

Veale, D. R., Smith, H., Witt, K. A., and Marshall, R. B. (1975) F. med. Microbiol., 8, 325 